\title{
A Small Entrepreneurial City in Action: Policy Mobility, Urban Entrepreneurialism, and Politics of Scale in Jiyuan, China
}

DOI:

10.1111/1468-2427.12631

\section{Document Version}

Accepted author manuscript

Link to publication record in Manchester Research Explorer

Citation for published version (APA):

He, S., Li, L., Zhang, Y., \& Wang, J. (2018). A Small Entrepreneurial City in Action: Policy Mobility, Urban Entrepreneurialism, and Politics of Scale in Jiyuan, China. International Journal of Urban and Regional Research, 42(4), 684-702. https://doi.org/10.1111/1468-2427.12631

\section{Published in:}

International Journal of Urban and Regional Research

\section{Citing this paper}

Please note that where the full-text provided on Manchester Research Explorer is the Author Accepted Manuscript or Proof version this may differ from the final Published version. If citing, it is advised that you check and use the publisher's definitive version.

\section{General rights}

Copyright and moral rights for the publications made accessible in the Research Explorer are retained by the authors and/or other copyright owners and it is a condition of accessing publications that users recognise and abide by the legal requirements associated with these rights.

\section{Takedown policy}

If you believe that this document breaches copyright please refer to the University of Manchester's Takedown Procedures [http://man.ac.uk/04Y6Bo] or contact uml.scholarlycommunications@manchester.ac.uk providing relevant details, so we can investigate your claim.

\section{OPEN ACCESS}




\title{
A small entrepreneurial city in action: Policy mobility, urban entrepreneurialism, and politics of scale in Jiyuan, China
}

\author{
Shenjing $\mathrm{He}^{1}$, Lingyue $\mathrm{Li}^{2}$, Yong Zhang ${ }^{3}$, Jun Wang ${ }^{4}$
}

1. Department of Urban Planning and Design, The University of Hong Kong, Hong Kong SAR, China; The University of Hong Kong Shenzhen Institute of Research and Innovation, Shenzhen,

China

2. Department of Urban Planning, College of Architecture and Urban Planning, Tongji University, Shanghai, China

3. School of Environment, Education and Development, University of Manchester, Manchester, UK

4. Department of Public Policy, City University of Hong Kong, Hong Kong SAR, China

Corresponding author: Shenjing He, Department of Urban Planning and Design, 8/F Knowles

Building, The University of Hong Kong, Pokfulam Road, Hong Kong SAR, China; The

University of Hong Kong Shenzhen Institute of Research and Innovation, Shenzhen, China

Email: sjhe@hku.hk

\begin{abstract}
This research details the mundane practices of policy mobility and entrepreneurial endeavor in Jiyuan in relation to the city's changing administrative position, and is one of first attempts to understand how entrepreneurial policies are mobilized, mutated and diffused in a small inland Chinese city. We interpret Jiyuan's evolving development strategies and trajectory through two interrelated conceptual lens of policy mobility and urban entrepreneurialism, bridged by the analysis of the politics of scale. Over the past three decades, governance strategies in Jiyuan have evolved from policy imitation under the germination of urban entrepreneurialism, to policy mutation and diffusion under the amplification of entrepreneurialism, as the city moves up the administrative level and urban hierarchy. Involving a multi-scalar process, policy mobility and urban entrepreneurialism in Jiyuan are being shaped by the interactions between the city, the region, the central state and global capital under the confluence of globalization and marketization. The "successful" story of a small entrepreneurial city tells a new tale that can inform wider contexts, through painting a fuller portrait of the evolvement of an entrepreneurial city across different scales and time, and bringing cities "off the map" back into the picture of urban entrepreneurialism against the backdrop of globalization.
\end{abstract}

Key words: entrepreneurial city; policy mobility; politics of scale; administrative hierarchy, small city, China 


\section{Introduction}

David Harvey's (1989) influential work on the transformation of urban governance in late capitalism triggered widespread excavations and experiments into the idea of the entrepreneurial city among scholars and policy makers (Jessop and Sum, 2000; Chapin, 2002; Biddulph, 2011; Doucet, 2013), and a context-sensitive examination of this theoretical notion will help limn the development model of China's interior cities. Unambiguously, the evolving entrepreneurial endeavors of Central Chinese cities are tied in with the asymmetric power decentralization, real estate boom and tax sharing reforms, but are also determined by its unique geographic location and development phase. As an authoritarian regime that is invigorated by neoliberalized economic policies (Peck and Zhang, 2013; Harvey, 2005), China has been utilized as a laboratory for the examination of "planetary urbanization" and the active intervention of government in urban development, as studies of urban China advance in parallel with the country's further engagement in the world economy (Brenner, 2013; Wu, 2016a; He and Qian, 2017).

With the deepening of economic reforms, planning in China is thriving and is being embraced enthusiastically by leaders of various ranks, who often act more like entrepreneurs than conventional bureaucrats. Planning in China under entrepreneurialism is omnipotent, being utilized as an effective tool for place promotion and city branding, thus providing legitimacy to the growth discourse preached by bureaucrats, while also imposing development control over the urban crises that are inherent in a market economy ( $\mathrm{Wu}, 2015)$. Planning practices are far reaching in promoting fast-track urban development, and exemplify the thriving urban entrepreneurialism that exists in China. Wu's (2003) pioneering analysis of Shanghai's globalizing planning strategies through the lens of urban entrepreneurialism rightly points out that post-socialist economies such as China demonstrate a strong "path-dependency" with distinct features of entrepreneurialism. Engaging with debates on the entrepreneurial city, the role of profit-motivated and adventurous local governments in promoting urban development has been examined in such major Chinese cities as Shanghai, Guangzhou and Hangzhou (Hubbard 1995, Duckett 2006; Qian 2011; Wu and Zhang, 2007). Notably, new town and eco-city planning, epitomizing land-driven expansionism, have become catchphrases in Chinese contemporary 
entrepreneurial planning policy (Caprotti, 2014; Chien, 2013a; Shen and Wu, 2012; Wu, 2012). Under the confluence of globalization, decentralization and marketization, entrepreneurial policies are filtering down through the urban hierarchy and spreading out to the lower tiers of cities in the country. That said, studies of entrepreneurial practice beyond large first-tier Chinese cities are few in number, although there are a few exceptions, such as the studies of Kunshan and Lijiang (Chien, 2013b; Su, 2015). In addition, how entrepreneurial policies are mobilized at multiple scales and fixed in particular local settings in China have been examined only very recently (e.g. Zhang, 2012).

This research examines policy mobility and urban entrepreneurialism in the small city of Jiyuan, which is located in Henan Province ${ }^{1}$ in Central China, looking at Jiyuan's evolving entrepreneurial path, in which entrepreneurial policies are imitated, mutated, and diffused at different locales and scales. Responding to Peck and Theodore's (2012) suggestion that policies should be followed beyond their genesis and initial transfer, this study traces the germination, amplification and diffusion of entrepreneurial policies in Jiyuan, and explores their longer-term impacts. We believe that scrutinizing policy mobilization in Jiyuan will allow a deeper investigation of its entrepreneurial pathway. Accordingly, this paper aims to shed new light on how a small inland Chinese city engages with urban entrepreneurialism as entrepreneurial policies transfer across different scales, how its entrepreneurial pathway is intertwined with the city's upgrading in the administrative hierarchy, and how these endeavors evolve over time. Looking beyond the major urban networks, this study contributes to the body of literature on policy mobility and urban entrepreneurialism in a localized context, and to bridge these two corpuses of literature through the lens of scale politics by articulating the special trajectory of evolving entrepreneurial policies and practices in Jiyuan, China. The "successful" story of a small entrepreneurial city and the resultant "Jiyuan model" tell a new tale that may not have been revealed by the entrepreneurial passages of global and world cities from several aspects. Firstly, Jiyuan, as an "ordinary" or even an inferior inland Chinese city, managed to move up the administrative hierarchy through more painstaking entrepreneurial endeavors, thus paints a fuller portrait of the evolvement of an entrepreneurial city across different scales and time. Secondly, through documenting the small inland city's endeavors to make its way to connect with global economy by mobilizing entrepreneurial policies cross-cutting multiple scales, the Jiyuan case presents a much needed attempt to bring cities "off the map" (Robinson, 2002) back into the

\footnotetext{
${ }^{1}$ Henan province is one of the most populous provinces in China. As of 2016, its population ranked the third, while its GDP ranked the fifth in the whole country, the top one in central and western China.
} 
picture of urban entrepreneurialism against the backdrop of globalization, which tends to be dominated by cities at the top of the urban hierarchy. Thirdly, and more importantly, the value of the Jiyuan case does not lies in its particularities that could easily be reduced to "yet another case study", but the richness of its complex story that generates more nuanced understanding of policy mobility and urban entrepreneurialism and informs wider contexts, if the city is taken as one of the nodes in the multi-scalar entrepreneurial urban networks embed in local politics.

\section{Conceptual framework}

\subsection{Policy mobility under entrepreneurialism}

The two interactive strands of literature of policy mobility and urban entrepreneurialism constitute an emerging research area in urban studies. Urban entrepreneurialism has prevailed since the 1980s when the active, innovative role of local governments was well-documented by a number of researchers in North America and Western Europe (e.g. Peterson, 1981; Rees and Lambert, 1985; Blunkett and Jackson, 1987). This entrepreneurial shift in local governance, as stated by Harvey (1989), was aimed at coping with the widespread erosion of economic and fiscal bases of large cities in the advanced capitalist economy. Entrepreneurial policies seek to create a business-friendly urban milieu within which mobile capital can be fixed, and in this regard, urban entrepreneurialism stands as an academic endeavor to unravel the global contemporary capitalist operation logic. While the issue of how the coercive forces of late capitalism exerts power upon the production of entrepreneurial policies has been addressed extensively, details have been largely overlooked of how policies and governance modes evolve, transfer and achieve in contested entrepreneurial cities (McCann 2013), where policy regimes are undergoing rapid change and are characterized by a pragmatism that embraces "policies that work" (Peck, 2011).

Studies of policy mobility provide a nuanced understanding of the mundane political practices that were learned from outside and taught elsewhere (Peck and Theodore, 2010; McCann, 2011; McCann and Ward, 2012). In transferring "best practices" through back-and-forth teaching and learning, policy mobility highlights how cities are produced and developed, both in and through, the inter-city, cross-scale circulation of policy knowledge. An analysis of inter-local policy flow may only involve one particular polity, but inquiry into transnational policy transfer demands an additional understanding of how the local act globally beyond single nation states (McCann, 
2011). The cities that are most visited by delegations become models, and are emulated by "transfer agents" through prosaic routines, site visits, personal connections, etc. In constant motion, the policy world is imbued with struggles to "get a move on" and to keep up with the fad tides (McCann and Ward, 2012). During the course of the circulation of policy knowledge from one jurisdiction to another (McCann and Ward, 2010), policies mutate as peripatetic policy entrepreneurs go on their capricious political journeys (Peck and Theodore, 2010). Unpacking the mechanisms of how policy mobility reshapes the urban agenda in neo-liberalized localities, thus, requires a complicated mapping of the flows and circulations of knowledge (Peck, 2011). Methodologically, unravelling how political authorities, through their policies and practices, produce intended or unintended outcomes necessitates an interdisciplinary approach to attain an in-depth understanding of urban policy formation (Peck and Theodore, 2010; McCann and Ward, 2012). To conceptualize policy mobility and mutation, Peck (2011) thus engages political science, comparative institutionalism and political sociology in the critical dialogue of policy transformation. It is worthy of note that policy pathways and their outcomes vary in different periods and localities where political ambitions, urban aspirations, institutional legacies and local conduits are discrepant (Brenner et al. 2010; McCann and Ward, 2012), and so historicalgeographical posture is therefore essential if one is to understand the hybrid mutations of policymaking across heterogeneous institutional landscapes.

Neoliberalism is mobilized globally, and so China is not in isolation. The reforms and opening up of the country have brought it into the global circuits of neoliberal policies, ineluctably hybridizing and interdigitating with the institutional legacies of the planned economy (Brenner et al., 2010). China's "loose hugs" with neoliberal policy models does not prevent these policies from being mobilized by the authoritarian state and adapted to the state-dominated urban growth regime (Harvey, 2005; Liew, 2005; He and $\mathrm{Wu}, 2009$ ). In the early stages, reform pioneers imitated and adapted the capitalist operations seen in coastal cities, as suggested by a commonly cited Chinese saying "crossing the river by feeling the stones". Their initial economic success was affirmed by Chinese Communist Party (CCP), which led to policies being translated for diffusion from the coast to the interior region, from first-tier large cities to medium and small cities, although the time-lag and contingencies of policy adoption as they filtered down the urban hierarchy were the main factors leading to inequality at a later stage. This "actually existing 
policy transfer" mirrors Stone's suggestion that the policy-making elite "import innovatory policy developed elsewhere in the belief that it will be similarly successful in a different context" (Stone, 1999: 52). Moreover, the modality of policy mobilization evolved into more hybrid forms under fiscal reforms, with the tax redistribution transforming the streamlined decentralization into a hybridity of power de/recentralization (Jia et al., 2014), known as "regionally decentralized authoritarianism" (Landry, 2008). As the power of the local is further unleashed by decentralization, Chinese cities have grown from toddlers to trailblazers in urbancentered capital accumulation, developing an active inter-referencing policy system, although these policy options are characterized by scant public participation, ubiquitous elite control and local discretion (Robinson, 2011). Unlike in Western democratic countries, responsibility for the transfer, promotion and dismissal of Chinese officials is in the hands of upper-level authorities, and often subjected to frequent changes even before the first term (usually four years) is over. As a consequence, policy-makers seek only to satisfy their higher-ups, and can overlook the needs of their subordinates and the grassroots groups. The floating cadre network enables policy mobility, yet frequent policy changes lead to unstable policy ambiences, and as a result, the intercity circuits of policy transfer in China are highly dynamic, but often formulaic within the political system.

\subsection{The politics of scale and China's administrative hierarchy}

Literature on scale from the past several decades has witnessed a conceptual shift, from scale to rescaling, and then to the politics of scale (Brenner, 2000; Harrison, 2008; Cox, 2013). With the transformation of the role of the state, from managerialism to entrepreneurialism, in post-Fordist societies, competitive and strategic developmental policies are commonly employed to induce crisis-reactive actions operating at transnational, subnational, regional, urban and body scales (Brenner, 2004; Smith, 1993). Politics of scale see scale/territory as something that is socially constructed and politically contested, being constantly produced and re-produced, and inevitably mutable and historic (Brenner, 2000; Swyngedouw and Heynen, 2003; Cox, 2013). Indeed, as McMaster and Sheppard (2004) point out, "the construction, ordering and maintenance of a particular scalar system is a complex historical-geographical achievement", and so the politics of scale demands inquiries into political agencies, institutional ensembles and entrepreneurial endeavors (MacKinnon and Shaw, 2010). 
From the theoretical perspective of scale, scholars urge for studies into China's administrative/territorial structure (Ma, 2006; Cartier, 2015). In China, places, with their defined administrative ranks and territorial borders, can be considered patches of political space, the reconfiguration of which demands the political power of the central state (Wu, 2016b). Given that, the "power decentralization process is in actuality a re-territorialization of the state, rescaling the state's functionality from the predominant national level to the level of the localities" (Wu 2003:1695). In this context, reconfigurations of administrative ranks and territorial borders have been undertaken since the early 1980s ( $\mathrm{Li}$ and $\mathrm{Wu}, 2012$ ). Serving different objectives, these changes take the forms of evident selectivity and variety, and furthermore, bring to the forefront the need, as advocated by Ma (2005, p481), to "unpack the prevailing view in the studies on state-local relations in China which tend to lump all subnational units below the level of the province in the category of the 'local' without further scale specificity".

Focusing on administrative levels and territorial borders opens a line of inquiry into the continuous reconfiguration of the spatial administrative structure of China's spatial economy. The position of a city in the spatial administrative hierarchy defines its jurisdictional power, the resources it possesses, the form and rank of the state apparatus and its officials, and its horizontal relations with the surrounding rural areas and other cities. Cities thus became the central terrain of the economic engine in the wake of administrative shuffling programs, such as the CityLeading-County policy of the 1980s. Upscaling a city to a higher rank bestows upon the given stronger jurisdictional power and a broader scope of discretion, and often involves a merger of multiple territorial units and the promotion of local political leaders, which thus become a "successful pathway" that is pursued enthusiastically by local bureaucrats in China. Based on the administrative zone economy concept, Cartier (2015) puts forward the idea of administrative urbanization to bring the state and politics back to the center of scholarly inquiries on urbanization, unraveling how strategic economic areas, as administrative territories that are produced by state reterritorialization for the projection of new visions, engender new political/economic arrangements.

Policy mobility under urban entrepreneurialism varies over time across different geographical 
areas and throughout the administrative hierarchy, with the germination and amplification of urban entrepreneurialism often suffering delays in the hinterland region. An area's position in the urban hierarchy and its administrative level also play an important role in determining when it will benefit from the transfer of entrepreneurial policies, and also the availability of political capital and economic resources for the implementation of entrepreneurial policies. A small county-level city in the hinterland region thus has double disadvantages in terms of the time-lag and the lack of political and economic resources in participating in the national and regional entrepreneurial network. There is a wealth of literature exploring China's urban entrepreneurialism at regional (Xu and Yeh, 2005, Luo and Shen, 2007, Li and Wu, 2012) and metropolitan (Qian, 2011; Zheng, 2011; Chan and Li, 2017) levels, whereas how entrepreneurial policies trickle down and are materialized at a county level has attracted less academic attention (Chien, 2013b). This stark lacuna necessitates the introduction of an analytical lens of scale is one is to understanding the policy mobility and entrepreneurial path of a small inland countylevel city, represented in this study by Jiyuan.

\section{The study area and data collection}

Jiyuan sits in northwest Henan, bordering the Shanxi province, and covers an area of 1,931 square km (see Figure 1). Despite its small population of 680,000, Jiyuan's rate of urbanization has surpassed 51 percent, and in 2012 it out-performed all other areas in Henan Province in terms of GDP per capita. Being the only sub-prefecture-level city ${ }^{2}$ in Henan Province, Jiyuan comprises 11 towns and five sub-district offices, and its development is deeply associated with its evolving administrative level and its position in Henan's urban hierarchy. It transformed from a county to a county-level city in 1988, was upgraded from a county-level city to a subprefecture-level city in 1997, grew as one of the nine central cities of the "central urban agglomeration scheme" in 2003, became a "model city" for integrated urban-rural development in 2005 and has been governed by prefecture-level city leaders since 2008. ${ }^{3}$ Jiyuan's success can

\footnotetext{
${ }^{2}$ A sub-prefecture-level city is an unofficial administrative rank accorded to Chinese cities. Although it is considered officially to be a county-level city, the cadres assigned to its government are half a level higher in rank than those of an ordinary county-level city, yet still lower than those of a prefecture-level city. While county-level cities are administrated by prefecture-level cities, sub-prefecture-level cities are often administered directly by the provincial government.

${ }^{3}$ China's party-state system comprises four major bureaucratic hierarchies: provincial/ministry level (Sheng-bu ji), prefecture/department level (Di-ting ji), county/division level (Xian-chu ji) and township/section level (Xiang-ke ji) (Chien, 2013b; Li, 2015).
} 
be attributed to the leadership of Li Changchun, the governor of Henan Province in the 1990s, who strongly encouraged county-led economic development, similar examples of which can be found in Dongguang and Zhongshan in the Guangdong province in coastal China, both of which have grown into prefecture-level cities. The trajectory of Jiyuan's evolution presents a valuable opportunity to examine how policy mobility and local entrepreneurialism are interdigitated with its rising position in the urban hierarchy, as in China, a city's administrative level dictates the availability of resources for local development. A study of the entrepreneurial path being followed in Jiyuan serves to expand the scope of the body of literature on entrepreneurial cities to small cities in the Chinese hinterlands, while also enriching our understanding of urban entrepreneurialism in association with policy mobility in a non-Western context. Taking this perspective, this study will scrutinize how Jiyuan's entrepreneurial policies and practices have evolved alongside its move up the administrative ranks and its position in the urban hierarchy.
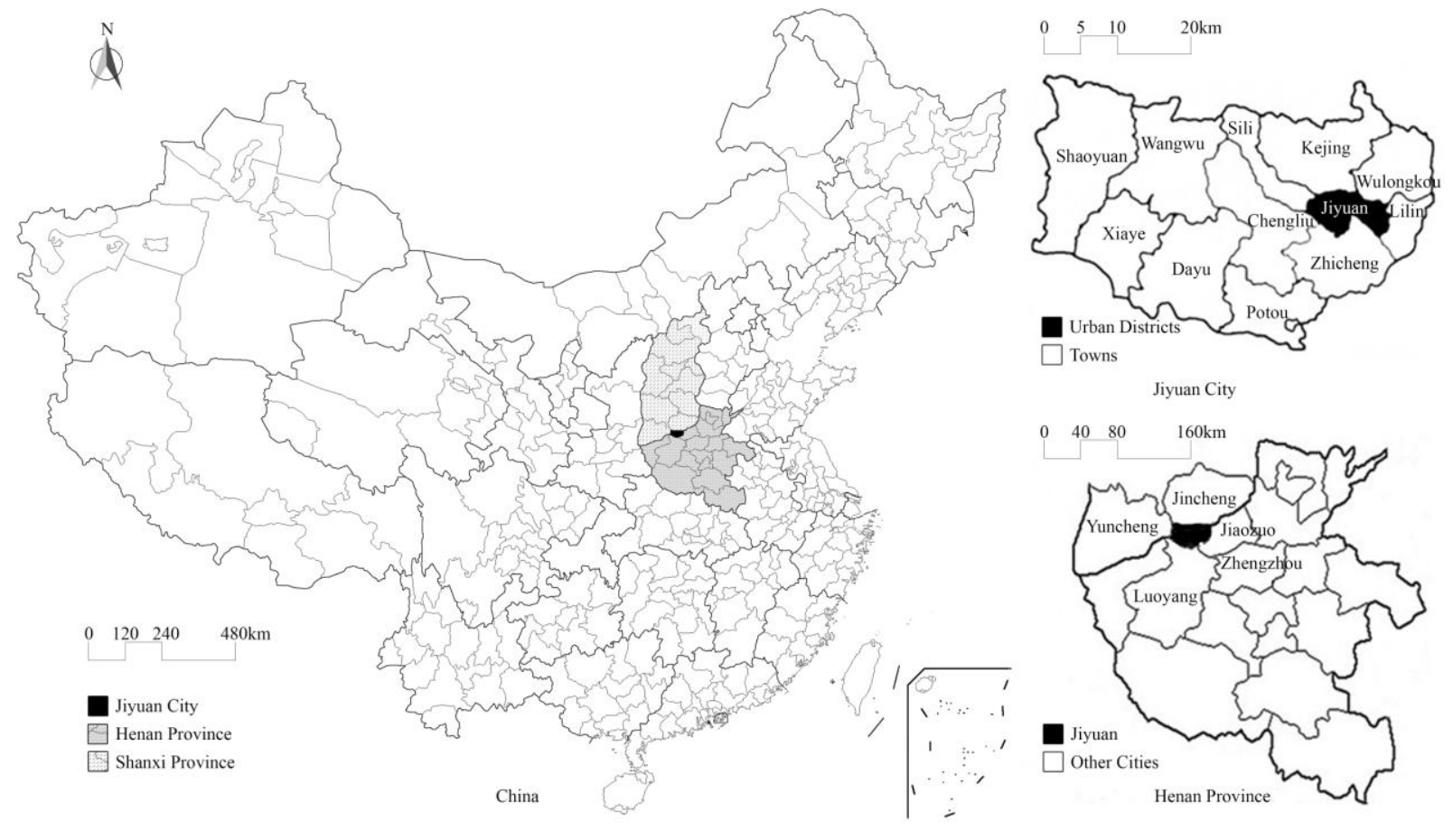

Figure 1 The location and administrative boundary of Jiyuan

(Source: compiled by the authors.)

The following sections look at the evolution of urban entrepreneurialism and mobile policies in two phases: from policy imitation under the germination of urban entrepreneurialism, to policy mutation alongside the amplification of entrepreneurialism. In time, as a successful 
entrepreneurial city model, Jiyuan's policy practices have been adopted by neighboring counties and cities that are eager to enhance their competitiveness in the hierarchical urban system, and the Jiyuan model was also scrutinized systematically by the Henan provincial government in its search for inspiration for its "counties and cities administrated directly under provinces" reforms at a provincial scale. Finally, a discussion is made of the theoretical and empirical implications of the Jiyuan case on policy mobility and urban entrepreneurialism in China, and its cross-cutting of multiple scales, highlighting also the value in understanding the distinct strategies and pathways of entrepreneurial policy mobility in small inland Chinese cities.

First-hand data was garnered during several field trips to Jiyuan in 2013 and 2016, when we interviewed several officials in the Jiyuan Land and Resources Bureau about the land development scheme in Jiyuan and collected unpublished land transaction data. We also interviewed representatives of the Industrial Development Bureau to understand Jiyuan's industrial growth history, as well as their strategies for attracting investment. Information on the Foxconn case was garnered from an interview with an official working in the "Serving Foxconn Project Development" headquarters, as one of the young cadres who had been transferred temporarily to this special office from the Business Bureau, and who provided us with detailed information about the negotiation and implementation process of the Foxconn project. We were also able to gain substantial insight into the spatial growth and city planning of Jiyuan during an interview with a professional planner working in the Urban Planning Design \& Research Institute of Henan Province who was engaged in the latest city planning of Jiyuan City. Numerous secondary data sources were accessed with the help of aforementioned interviewees. These data include historical archives, statistical yearbooks, official government reports from 1997 to 2016, three official websites of the industrial parks, and planning documents related to the Urban and Rural Master Plan (2012-2030).

\section{Policy mobility and evolving entrepreneurial endeavors amidst Jiyuan's shifting administrative position}

As manifested in its peculiar engagement with policy mobility and its crosscutting of different scales, Jiyuan's path of urban entrepreneurialism is connected intimately to its rise up the 
administrative rankings and the associated vision that evolved out of the country-level city's local-based strategy. In its most recent manifestation, the sub-prefecture-level city's ambition to be a part of the "rising central China" has been articulated to promote integrated urban-rural development (see Table 1). Accordingly, its urban policies have evolved, from imitating the east coast to self-mutation.

Table 1 Jiyuan's evolving development vision since 1978

\begin{tabular}{|c|c|c|}
\hline Year & key event & Designated urban function (vision) \\
\hline 1978 & Reform and opening up policy & A gateway city to the northwest Henan Province* \\
\hline 1988 & $\begin{array}{l}\text { Upgraded to be a county-level } \\
\text { city }\end{array}$ & $\begin{array}{l}\text { A regional central city with low-pollution industries and tourism oriented } \\
\text { development }\end{array}$ \\
\hline 1998 & $\begin{array}{l}\text { Upgraded to be a sub- } \\
\text { prefecture-level city }\end{array}$ & $\begin{array}{l}\text { A national energy base, a renowned historical and cultural city and a } \\
\text { central city in the region of northwest Henan Province and southeast } \\
\text { Shanxi Province. }\end{array}$ \\
\hline 2006 & $\begin{array}{l}\text { Designated as one of the pilot } \\
\text { cities implementing urban-rural } \\
\text { integration }\end{array}$ & $\begin{array}{l}\text { A national energy base, a provincial renowned historical and cultural city } \\
\text { and an emerging industrial and tourism city }\end{array}$ \\
\hline 2012 & $\begin{array}{l}\text { Joined the Central Plains } \\
\text { Economic Zone ("rising central } \\
\text { China") plan approved by the } \\
\text { central government }\end{array}$ & $\begin{array}{l}\text { A burgeoning central city, an advanced manufacturing and energy base, } \\
\text { as well as a model city for urban-rural integration in the Central Plains } \\
\text { Economic Zone. }\end{array}$ \\
\hline
\end{tabular}

Source: Urban-rural master plan of Jiyuan City: 2012-2030; Government Work Report of Jiyuan City: 1997-2015

Note: * Specific description of city orientation was missing in the official documents. This was a typical narrative of Jiyuan's strategic location since the ancient times from other sources.

\subsection{Policy imitation under the germination of entrepreneurialism}

Jiyuan's entrepreneurialism gained speed in the late 1980s when Henan Province decided to develop a county-level economy in a bid to reconfigure its poverty-stricken image. Among all the 108 counties, the Henan provincial government designated 18 counties as "Special Counties for Pilot Experiments" (SCPEs), ${ }^{4}$ granting them partial economic discretion at a provinciallevel. ${ }^{5}$ With its new-found discretional power, Jiyuan was able to apply innovative policies as an early form of entrepreneurial practice that were, on the whole, adapted policies from outside.

\footnotetext{
${ }^{4}$ Jiyuan is one of the SCPEs in Henan.

${ }^{5}$ Discretional power includes expanded approval rights of the county government, stabilized tenure for the upperlevel leaders in counties, direct cadre management of county party secretaries and county magistrates by the Provincial government, and direct submission of county projects to provincial departments for examination and approval.
} 
Initially, local political leaders attempted to emulate town and village enterprise (TVE) development strategies from Jiangsu and Zhejiang, two developed provinces on the east coast where focus is on bottom-up rural industrialization. Despite best efforts, the adoption of policies from the highly developed east coast urban agglomerations were unsuccessful, in that Jiyuan's rural economy was too fragile to support the required market reforms, typifying the time-lag and contingency of policy mobility in a vast country that has long suffered from regional disparity and a rigid administrative hierarchy. After the failure of many TVE experiments failed from 1984 to 1987 , the Jiyuan government realized that rural capitalization was not feasible due to the lack of equipment, skilled labor and capital. Meanwhile, a wave of state-owned-enterprise (SOE) reforms were surging at the national level, leading to prevalent SOE auctions in Henan Province. Trapped in a dilemma, Jiyuan refocused its efforts on SOE reforms in a search for alternative approaches to local economic development. It is worth noting that at the time, SOEs would often run deficits for years, being either too small to compete with their counterparts elsewhere, or under the control of an inefficient and outdated management structure. To reverse the downturn, the Jiyuan government expanded the scale of SOEs and provided a series of incentives to optimize the management of SOEs, and these incentives were augmented in the early 1990s when a new secretary general was appointed to the city government. In the period that followed, the City Party-Committee, bypassing the bureaucratic hierarchies, took direct control of the management of municipal SOEs, and six underperformed factory managers were removed from their positions. A series of steps were taken to enhance the accountability of SOE leaders, including incentives to outstanding leaders, and preferential policies were put in place to nurture young and promising entrepreneurs. As Jiyuan shifted its entrepreneurial strategy from TVE development to municipal SOE reforms, underwritten by the nurturing of entrepreneurship in SOEs, the common practices of rural industrialization and privatization in the 1990s were subverted. This had emerged in a particular development stage of the city as a result of its disadvantageous geographical and socioeconomic position in the Chinese urban network.

Implementing institutional innovation in SOEs, promoting entrepreneurial spirit and seizing strategic opportunities were the basic characteristics of the burgeoning urban entrepreneurialism in Jiyuan, with strong path-dependent features. In Jiyuan, the burgeoning entrepreneurial spirit led also to special focus on education and infrastructure development. In 1993, 100 million RMB 
was invested into the building of vocational schools, and in the same year, two national projects - the Xiaolangdi Water Control Project and the Qinbei Power Plant - were launched. During the period of the Ninth Five-Year Plan (1996-2000), a special budget was allocated to further develop the road system that amounted to almost 2.5 times the total investments since 1949 . Although the city was successful in attracting foreign capital in 1992, it remained dominated by the endogenous development of municipal SOEs. To publicize the "Jiyuan model", which was based largely on SOE reform, the debate over "public" or "private" ownership remained central to the city's entrepreneurial discourse.

In summary, Jiyuan's entrepreneurial practices began by imitating the rural industrialization policies being applied on the east coast in the early 1990s, but constrained by deficiencies in capital and skilled labor, Jiyuan had to develop a path-dependent growth model that relied mainly on SOE reform and public investments. Jiyuan's early entrepreneurial endeavors thus entailed a path-dependent yet effective entrepreneurial strategy. Strong scaling and hierarchical effects were revealed in this process of policy mobility, whereby successful entrepreneurial policies that had thrived in developed city regions may not bear fruit in less urbanized and developed inland regions, as they filter down to the lower end of the hierarchy. From emulating TVE development to the marketizing of SOEs, Jiyuan performed like a toddler learning marketized operation, falling far short of forming an outward-oriented entrepreneurial discourse.

\section{2 Policy mutation with amplified entrepreneurialism}

Policy mutation refers to changes in policy that occur across time and space. Policy must be revamped when transplanted to a new soil or as it evolves in different phases, in that policy mobility is inherently a back-and-forth learning and teaching process (Peck and Theodore, 2010; McCann, 2011). In this regard, mutation is inevitable when policies travel horizontally between cities of similar scale/hierarchy, or vertically across different scales/hierarchies and in different periods of time, as these power-laden processes involve so many actors who constantly interpret or reinterpret these policies (McCann and Ward, 2012). The initial failures in policy imitation did not impede Jiyuan's persistent exploration of urban entrepreneurialism. After the Eighth FiveYear Plan (1991-1995), Jiyuan's entrepreneurial practice expanded even further, taking the city into the list of the 100 top-performing counties consecutively in 1994 and 1995. Time and space 
reshape policies as they excurse, leading Jiyuan to make its own interpretation of the widespread entrepreneurial strategies of "city marketing" and "outward-orientation". Policy mutation in the wake of Jiyuan's amplified entrepreneurialism comprises two phases: city-based place marketing, and outward-oriented strategies, both of which are related to the rescaling of entrepreneurial policies and the shifting administrative position of Jiyuan.

\subsubsection{City-based place marketing as self-amelioration}

In around 2000, the path-dependent economic development model underwritten by the SOE reforms came to be replaced by a market-oriented and private investment-led economy. Jiyuan's policy mutation was supported primarily by its remarkable economic achievement in the 1990s, which encouraged policy makers to push for further "power decentralization" in a bid to take the county-level city further up the ladder of scalar politics. After intensive debates inside the Henan provincial government that resulted in the adoption of a "province administering county" model, Jiyuan was granted sub-prefecture status in 1998. The official implementation scheme for this "province administering county" model announced by the Henan Provincial government makes detailed arrangements at operational levels, of which four main features are worth noting. Firstly, the management of three large SOEs within Jiyuan administrative region was transferred from Jiaozuo (the prefecture level city above Jiyuan) to Jiyuan. Secondly, administrative units at a provincial level took over responsibility for the departments of electricity, transportation, postage and banking in Jiyuan, with no interventions from Jiaozuo. Thirdly, the provincial government is responsible for Jiyuan's economic and social development plans making, and its financing and taxing systems, and makes the same redistribution arrangements for Jiyuan as other prefecturelevel cities in the Province. Last but not least, the four local state mechanisms, being the PartyCommittee, the Government, the People's Congress (PC) and the Political Consultative Conference (PCC), were all upgraded to the sub-prefecture hierarchy in the national bureaucratic system. Under this reform of the administration system, Jiyuan became subtly distinguished from other provincial-administering pilot counties at the time, paving the way for the adoption of a city-based rather than a simply industry-based development strategy for the new millennium. The administrative upscaling of Jiyuan had a fundamental impact on the paths of policy mobility and entrepreneurial endeavor in the city, in that the city's new administrative power came with increased access to political and economic resources, as well as discretional control, bringing 
about a rise in outward marketing strategies. This special arrangement for Jiyuan beyond the "orthodox" administrative hierarchy can be seen as an institutional innovation of "scalejumping", breaking the constraints imposed by Jiyuan's relatively low administrative position to mobilize and operationalize various entrepreneurial policies.

Specifically, Jiyuan's entrepreneurial strategy shifted from being SOE-based to city-oriented, augmented by a series of city marketing strategies such as land and real estate reforms, the making of a "basketball town", an image making movement, and service oriented development (SOD) projects. Since the 1990s, land and housing development has become the major source of revenue for local governments. Thanks to Jiyuan's administrative upgrading and its relative independence since 1997, even before the establishment of the Ministry of Land Resources at the national level, the city no longer has to bargain with its affiliated prefecture-level city (Jiaozuo) in its fight for a share of the limited land-development quota, as many other county-level cities have. In 2003, as one of the eight "Basketball Cities" designated by the National General Administration of Sports, Jiyuan invested 180 million RMB for the construction of a basketball town, including a major stadium. It is highly debatable whether a small town like Jiyuan, with barely 600,000 residents, warrants the construction of such a large-scale, national-standard basketball stadium, although public criticism was soon quenched by the then Party Secretary in Jiyuan, who proclaimed that "only well-crafted nests attract phoenixes" and said that "basketball would be Jiyuan's city brand". Whether the production of new consumption spaces led by the "basketball town" strategy will be a success is yet to be seen, although as a new landmark, the basketball town has been seen, together with the "cultural town" and city library, other two local landmarks, to attract the interest of tourists and businessmen alike. Meanwhile, Jiyuan has endeavored to beautify the urban built environment and to promote the city brand. Various "image-making" campaigns have been launched by the local government, which has mobilized all social forces in national competitions to gain such titles as "National City of Civilization" and "Nationally Advanced Sanitary City". After Jiyuan directly administered by Henan provincial government, the city launched a "National Advanced Sanitary City" campaign that lasted for almost nine years. The term "place promotion" emerged as a catchphrase in city marketing efforts in Jiyuan, which had been witnessed previously in the Beijing Olympics, World EXPO in Shanghai and Asia Games in Guangzhou campaigns, with decision makers acknowledging that 
this campaign would not only promote the city image, but also facilitate urban renewal and urban expansion. This was part of the city's active imitation of the "best practices" of global cities in developed market economies and highly developed first-tier cities in the country, which would then filter down to the smaller cities in the less-developed hinterland. In a search for "policies that work" (Peck, 2011), local adaptations and policy mutations can be considered vital, and in this regard, Jiyuan's urban transformation is often associated with a service-oriented development (SOD) model in which development funds are attracted by providing public facilities/services in new urban areas. In short, the SOD model requires administrative intervention in the provision of public goods, and this typifies the trajectory of Jiyuan's spatial expansion over the past decade, as shown in Figure 2. Prior to 1997, the city had expanded along the main east-west transportation corridor, but under the influence of SOD, land expansion was redirected along the east-west to north-south axis from 1997 to 2005. Most evidently, urban construction saw a rapid escalation in the southeast, to where the city government had relocated in 2003, and this proved to be a determining factor in the urban expansion, the relocation of major administrative functions and the augmentation of government revenue in Jiyuan. In the early 2000s, a new master plan was drawn up for the underdeveloped areas to the south of the city that foresaw the creation of a new development zone, which was soon followed by rapid urban development. These development models exemplify the distinct features of administrative urbanization in China (Ma, 2006; Cartier, 2015). 

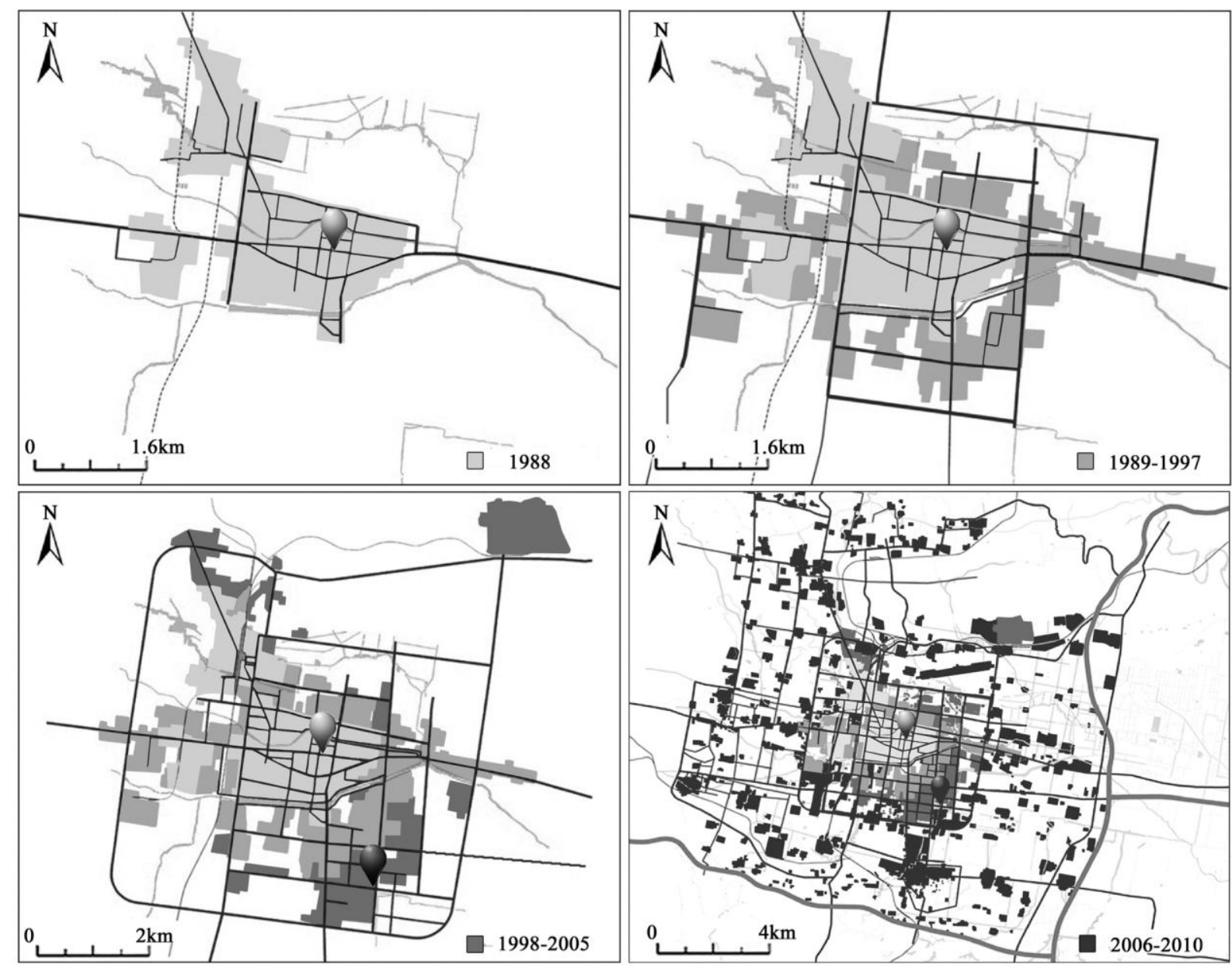

Former Site of Municipal Government

Current Site of Municipal Government

Figure 2 The expansion of Jiyuan city since 1988

(Source: compiled from local planning documents)

Although marketing strategies had prevailed in Jiyuan in the late 1990s, it wasn't until 2002 that the term "city marketing" was used for the first time in an official government report exploring an effective urban growth model. The term would reappear in the two following years in Jiyuan's annual government report, but with a shift in focus from land-based revenues in the initial stage, to publicly funded infrastructural construction. In 2001, the term "entrepreneurial government" appeared in a government report that positioned innovation as the centerpiece in the revitalization of the bureaucratic system. This breakthrough, brought potential risks to the traditional bureaucratic system, but was expected to contribute to Jiyuan's local institutional reforms and improve the city's development path in the long term. That said, Jiyuan's marketing strategy can be considered a proactive local action in response to the National City promotion 
campaign. Jiyuan's administrative upgrade to a de facto prefecture-level city changed significantly how it connected to the national and regional network of policy mobility, in that it is now able to react to national policies more directly and promptly rather than constrained by its upper level prefecture city. As a proactive learner in China's surging tides of economic reforms, different adjustments have been tailor-made, as reflected in the process of policy mutation, allowing the city to fit into its own unique position with the resources it has gained access to at different stages.

\subsubsection{Outward-oriented strategy to be integrated into global production}

In the Eleventh Five-Year Plan (2006-2010), Jiyuan was promoted as a model of integrated urban-rural development in the Central Plains Economic Zone (CPEZ) Plan, and soon after, a new round of administrative level upgrades were introduced to permit the adoption of the overall prefecture-level administrative organizational model, including the promotion of political leaders. By positioning urban-rural integration at the center of Jiyuan's development strategy, the local government proactively echoed the development ideology promoted by the provincial government. In this regard, urban-rural integration discourse is exploited to serve local entrepreneurial targets, while social equity, which is at the core of urban-rural integration, is largely ignored by the local government. This led the Jiyuan government to become more of a proactive entrepreneur than a follower in its interactions with its upper-level governments. It is worth noting that, Jiyuan's new positioning, as one of the nine major cities in the central urban agglomeration and an experimental site for integrated urban-rural development, has had a farreaching influence on its reorientation (see Table 1).

During this phase, Jiyuan initiated more outward-oriented entrepreneurial practices, which are reflected in all three indispensable entrepreneurial elements, and point to a process of policy mutation. In the early 1990s, a number of municipal SOEs began to export their products to overseas markets, including float glass, produced by the Benyue Group, special steel, made by The Central Plains Steel Co. Ltd., and lead smelting products, made by Yuguang Gold \& Lead Co. Ltd. More recently, Jiyuan has managed to channel large volumes of FDI into its main industrial clusters in 2013, although this outwardness remains immature, as its industrial structure is imbalanced and FDI attraction is resource-based, which means that Jiyuan is only 
loosely integrated into the global production network. This is again related closely to its disadvantaged position in the urban hierarchy, although the city continues to explore other marketing strategies, such as land financing and public-private partnerships, and from 2007 to 2010, the ratio of land leasing income to local revenue had soared from 10 percent to 31 percent. In August 2011, the Public Resource Exchange Center, incorporating multiple functions of construction, government procurement, real estate and property rights transactions, was established, improving greatly the quality of trading services in Jiyuan, and this organization has also benefitted Jiyuan's outward-oriented strategy, in particular, in FDI attraction, by providing efficient land resources services to targeted enterprises.

The entrepreneurial endeavors of the Jiyuan government in attracting FDI can be seen clearly in its efforts to secure investments from the Foxconn Technology Group, a Taiwanese multinational electronics manufacturing company. Henan's proactive approach to Foxconn can be traced back to 2007 when the "Foxconn Investment Coordination Leadership Team" was set up. The 2010 Foxconn suicide scandal and the lack of workers in east coastal China accelerated Foxconn's multi-locality production strategy and its active search for hinterland markets. With support from the Henan provincial government, Jiyuan signed a contract with Foxconn in March 2012, according to which the company would set up local production assembly lines under a broader cooperative framework between Zhengzhou - the capital of Henan Province - and Foxconn. This agreement took advantage of an array of favorable policies offered by Jiyuan, including exemption from land rents for 10 years, reimbursement of tax revenues for five years, and assistance in building the factory and recruiting employees. With the support of the entrepreneurial government in administrative procedures, it took only 180 days for the production lines to enter into in operation. This unconditional support was no different from that seen in China's east coast regions, where the once enthusiastically introduced traditional laborintensive and even polluting manufacturing industries are now being gradually transferred to the hinterlands.

The attraction of resource-based FDI increases the imbalance in Jiyuan's industrial structure, which is dominated by heavy industry. Since the economic reforms, the proportion of secondary industry, the economic pillar of Jiyuan, has grown from 42 to 75 percent. Heavy industries, 
including those involved in energy, iron and steel, and nonferrous metals, contribute much to Jiyuan's local revenues, however the consequent environmental pollution and health risks pressed the Jiyuan government to formulate new strategies, and in 2007, a proposal was chaired to move the polluting industries out of town or up into the mountains. In addition to the high-tech industrial development zone in southeast Jiyuan, two industrial agglomerations were established to incubate high-tech industries, and to raise funds for these industrial agglomerations, Jiyuan set up the City Investment Company to manage public financing and to forge extensive publicprivate partnerships to operate BT (buy-transfer) and BOT (buy-operate-transfer) models. Economically, these three industrial agglomerations perform well, generating RMB60.5 billion in business revenues in 2011, as well as RMB12.2 billion of investments in fixed assets, RMB5.4 billion in investment funds, and RMB1.29 billion in tax income. This constituted a significant proportion of Jiyuan's total economic growth.

Since 2000, entrepreneurial endeavors in Jiyuan have witnessed a shift from city-based place marketing to outward-oriented economic activities and industrial upgrading to the city's own development needs. These entrepreneurial strategies, which had seen some success in the country's more developed regions since the late 1990s and early 2000s, are now being embraced enthusiastically in Jiyuan. During the process of policy mutation, although still lagging far behind the east coast cities, Jiyuan is striving to keep up with the tides of entrepreneurialism that are surging in post-reform China by actively absorbing and modifying policies that have been adopted in higher ranking and more developed cities.

\subsection{Policy diffusion: how can the Jiyuan model be taught elsewhere}

In China, the term "model" is in common use in local government when there is a need to highlight success in policy advancement. As a small city with the highest GDP per capita in the province, Jiyuan's development pathway over the past decades was naturally packaged by the local government as a model that could be transferred to other places. From a county-level city, to province-administrated county, to sub-prefecture-level city, Jiyuan's entrepreneurialism has germinated and amplified along with its changing administrative position. The unfolding entrepreneurial strategies and endeavors in Jiyuan illustrate a legendary process that is replete with competitiveness and outward ambition, and is earnestly learnt by neighboring cities. 
Jiyuan's embryonic policy diffusion began in the early 1990s when it has gained fame as the only top-100 county in the country within Henan Province. At that time, official media and even academic publications had painted a picture of Jiyuan as a successful "model" of a developing county-level SOE. In an published article about economic development in central and western China, Jiyuan was depicted as a transferable model in the inland region (Chen and Chen, 1996), with five constituent parts: (1) improved transportation and promotion of urban construction; (2) prioritizing talent cultivation; (3) facilitation of tertiary industry development and transformation from being government-dominant to government-led; (4) developed non-state economy; and (5) relaxed policy constraints for FDI attraction.

In 2011, Jiyuan was further lauded by the national media as a development model for other small cities. Jiyuan's experience illustrates primarily that urban entrepreneurial strategies and orientations are related directly to the city's administrative position. Unlike such first-tier metropolises as Beijing, Shanghai and Guangzhou, where being recognized as a "global city" is the ultimate goal, Jiyuan's entrepreneurial orientation has evolved gradually as its administrative rank scales up from a northwest gateway city of Henan to a regional hub serving both the province and southeast Shanxi. In fact, to overcome the development hurdles associated with its double disadvantages (geographical and hierarchical position), Jiyuan has made some bold moves, such as building a CBA (Chinese Basketball Association)-standard basketball stadium to raise its urban profile. Additionally, infrastructure investments, especially into highways and railways, have been exploited as a key strategy in helping the less-developed small city to overturn its disadvantageous position. In Jiyuan, two major national railway lines, Jiaozhi and Houyue, intersect, and a major national highway passes through the city, connecting it to several other national highways. Such a highly developed transportation system grants Jiyuan a vantage point in the development of a logistic sector, and, more importantly, a strategic position in Henan and Shanxi's overall development plans. As a common strategy for local governments in China in their efforts to become embedded into the division of labor in the world economy, Jiyuan's efforts to attract FDI were relatively successful, actively responding to the "rising central China" and Central urban agglomeration strategies proposed by the central state. With the deepening of the opening up policies and the favorable tax incentives, land provision and administrative 
approval procedures offered by the local government, Jiyuan's actual use of FDI has been constantly exceeding the average growth rate in Henan Province since 2008. The forming of industrial agglomerations to enhance industrial strength, as can be seen in the successful development of high-tech industrial development zones in Jiyuan, is also a transferable tactic to be learnt by small cities, as this will allow them to be more competitive in the multi-scalar urban networks.

Bolstered by its outstanding economic performance, the policy diffusion from Jiyuan has accelerated in recent years. According to the official website of the Jiyuan government, in the 2013-2015 period, delegations from neighboring counties and prefecture cities, and from further afield, flowed into Jiyuan to learn from its development experiences, and were amazed at Jiyuan's succeses. It is widely believed that Jiyuan has accomplished a high-standard of urban construction with a solid industrial base, and that its development policies deserve to be widely diffused. This success has opend the doors to promotion for the political leaders of Jiyuan, with two consecutive former party secretaries in Jiyuan being promoted to the position of party secretary of Puyang, a prefecture-level city in northeast Henan. Although boasting a much larger population and administrative area, as well as a higher administrative rank, Puyang has been experiencing much slower growth and a lower urbanization ratio over the past decades than Jiyuan, and it also has a less stragetic postion than Jiyuan in the national plan. ${ }^{6}$ The cadre transfer within Henan helps diffuse the development experiences from Jiyuan to Puyang, which resembles the "Sunan cadres serve in Subei areas" pheonmenon seen in Jiangsu Province (Chien and Zhao, 2016). In early 2015, delegations from Puyang made a special trip to Jiyuan to learn about how FDI can be fixed and operated locally, and soon after, in August the same year, a Foxconn project was launched in Puyang. Moreover, Jiyuan's economic success has also benefitted Henan Province as a whole. Notably, after implementing an experimental reform commissioned by the State Commission Office for Public Sector Reform (SCOPSR) for three years, the Henan provincial government published a 'Province Administering County Implementation Plan', based partly on Jiyuan's experience, to officially inaugurate a new round of reforms in 10 county-level cities. Evidently, Jiyuan is leading an entrepreneurial campaign

\footnotetext{
${ }^{6}$ In the Central China Urban Agglomeration Development Plan issued by National Development and Reform Commission in December 2016, covering five provinces and 30 cities, Jiyuan was included in the core development area, while Puyang was positioned in the "radiation area".
} 
among small cities in Henan Province that may in the future be further diffused to other Chinese cities.

Despite all this, there are still some notable defects in the "Jiyuan model", and the efforts of the Jiyuan government to promote urban-rural integration have been problematic in many aspects. For instance, the applied policies have brought about a transformation of fertile agriculture land into urban construction land, with complete disregard for the protection of agricultural land. The "urbanized" rural residents who lost their farmland as a result of the "urban-rural integration" have received very little support from the local government. In particular, the lack of any employment training offered by the local government has turned many landless farmers into urban unemployed. Furthermore, Jiyuan's FDI growth has not guaranteed sustainable and highquality development, as the efforts to fix capital within Jiyuan's territories have been mainly resource-based, low-end and homogeneous to individual cities. In addition, the entrepreneurial strategy of Jiyuan mirrors the trajectory of China's primitive capital accumulation, which is at the cost of the natural environment and people's livelihood. As a sub-prefecture level city, Jiyuan occupies a relatively low position in the Central Urban Agglomeration, and plays a less significant role in Foxconn's global-local production network, which has weakened its ability to attract capital flows, which may limit any future upgrades in the urban hierarchy. With local governments enhancing their powers and skills in negotiating FDI, hopefully the race-to-thebottom competition will change in the near future.

\section{Discussion and Conclusion}

This research is one of first attempts to understand how entrepreneurial policies are mobilized, mutated and diffused in a small city in Central China, which is intimately interdigitated with cities of different scales in different geographical locations. The study goes beyond first-tier metropolises to detail the practice of policy mobility in Jiyuan, and examines the specific effects of policy mutation and diffusion that are closely connected to the city's changing administrative position. The path of entrepreneurial policy mutation and diffusion in Jiyuan demonstrates some distinct features, in which the unparalleled role played by the local government and its negotiations with multiple levels of government in initiating and sustaining the circuit of entrepreneurial policy mobility as it moves up the urban hierarchy merits special attention. 
Existing literature on entrepreneurialism and policy mobility often overlooks the dimension of scale, especially the administrative role of the state and the position of a city in the urban hierarchy. Yet, policy diffusion in China is more or less a top-down process in which the omnipotent state administrative power enables and facilitates the diffusion. Policy mobility is largely reliant upon the administrative structure, as "trans-urban networks of learning" are yet to be formed in China. The main contributions of this study, in this regard, are in its articulation of how entrepreneurial policies travel and mutate alongside the complex inter-scalar politics between different administrative levels, especially the mechanism of cadre promotion/transfer, and how administrative positions and inter-scalar politics constrain and facilitate Jiyuan's entrepreneurial endeavors.

The level of policy mutation and diffusion differs from locale to locale, with a city's geo-location, local politics, administrative position and city scale all playing a role. The access of small cities to financial and political resources is tied to its position in the urban hierarchy, which largely determines the localized emulation and mutation processes and the level of diffusion of mobile policies. With sufficient resources and support, cities at the top of the urban hierarchy often become pioneers of institutional innovation, and so are able to boost "policy tourism" (Ward, 2011). In the case of Jiyuan, its double disadvantageous position as a small hinterland city has led to delays in the implementation and diffusion of entrepreneurial policy. That said, the path of Jiyuan's evolving entrepreneurial policy mobility, associated with its inferior position, tells an intriguing story of entrepreneurial urbanism and policy mobility, intertwined with the complex politics of scale associated with its upgraded administrative level and its interrelationship with governments at multiple scales.

The entrepreneurial nature of China's local governance and the associated mobile policies/models have been influenced strongly by gradualist reforms, in which the power structure changes frequently. The politics of scale in China, especially the hierarchical administrative structure and its internal variations and alternations, affects, and sometimes even determines, the forms, modalities and pace of policy mobilization. The so-called "Jiyuan model", which has had a spillover effect into the surrounding region under a highly competitive ambience, has captured considerable attention from political leaders of neighboring small cities and 
counties, and even officials from the provincial government and other regions, who are eager to boost economic development in their areas of responsibility. Developing successful policy models that have been learned and adapted from large east-coast cities and diffusing them into other locales usually paves the way for a city to move up the urban hierarchy, and can bring promotion opportunities to successful local leaders. Such promotions are decided in line with China's cadre promotion system, in which a cadre's achievements are measured in terms of the economic performance and development of the jurisdiction they serve. Regular conference communications and delegation visits serve as platforms for the dissemination of successful policy models, for the building of connections among local bureaucrats and for the creation of a competitive arena. In this regard, policy mobility is closely connected with, and also consolidates, the hierarchical political system in China. Another means of policy diffusion is through cadre transfer, which brings successful past experiences to new areas. By transferring former party secretaries of Jiyuan to Puyang, successful policy knowledge was circulated to different jurisdictions, demonstrating how the institutional design of cadre transfer in China improves policy mobility. The goal of creating "reproducible and promotable" models in the Party system also encourages the development of pilot policies that can be quickly learned, implemented and diffused. This efficiency-first ideology of the Party leadership accelerates the pace of policy mobility in China in various aspects.

Scale also offers a useful conceptual lens for the comprehension of both the constraints and opportunities faced by Jiyuan during its evolving entrepreneurial urbanism. Owning to its comparatively low administrative status, Jiyuan's outward-oriented strategy continues to be resource-based, though supplemented by profit-garnering administrative approaches. Jiyuan's low status is related not only to its small size, but also to the fact that the overall competitiveness of Henan Province is relatively weak. Although Jiyuan substantially outperforms other counties and county-level cities, its economic volume remains far smaller than that of prefecture-level cities. Moreover, Henan failed to perform in a national competition to establish "experimental zones of comprehensive reforms", such that Jiyuan's new position as a "booming central city" was not able to be anchored until the "Central Plains Economic Zoning (CPEZ) Plan (20122020)" - proposed jointly by the five provinces Central Chinese provinces of Henan, Shanxi, Hebei, Shandong and Anhui - was approved by the State Council. All of this evidence points to a 
strong inter-scalar impact in which Jiyuan is not only affected by the upper level authority to which it is affiliated, but also closely embedded into the wider region at the upper scale.

On the other hand, although China's rigid bureaucratic system has constrained Jiyuan's capacity for policy emulation, mutation and diffusion, it has nonetheless benefited the city economically by providing a latecomer advantage against a backdrop of industrial restructuring, and politically by offering ample opportunities for administrative upgrades and cadre promotion through the "promotion tournament model". 7 The upgrading of Jiyuan is indicative of an outward-oriented process that is characterized by city-based inter-scalar competition among cities of various ranks and sizes. This is best manifested in the Foxconn case, where multinational corporations reassemble their production networks and seek global opportunities to spatially fix their surplus capital, while cities in the less-developed regions compete fiercely for such opportunities. The amplification of entrepreneurialism in Jiyuan therefore entails a profound reshuffling of power and capital in the global-national-provincial-urban rescaling process. In China, while power decentralization and the neoliberal economic policies put in place by the central government incentivize cities to compete enthusiastically for global capital flows, competition at a provincial level (e.g. among Henan, Hubei and Hunan) necessitates a regionalized entrepreneurial strategy in which intra-provincial cooperations are deployed, aimed at consolidating infrastructure development and attracting flagship projects. Furthermore, inter-city cooperations are driven by forces from both "below" and "above", with forces from "above" aiming to avoid vicious competition; and forces from "below" (e.g. twin-city, inter-city-integration) seeking to overcome administrative barriers so as to minimize transaction costs and prevent the effects of decreasing investment. It is worth noting that in situations where the assessment criteria of a "promotion tournament" clashes with the potential benefits of regional cooperation, or when upper-level governments fail to coordinate with lower-level authorities, such regional cooperations are likely to be fragmented and unsuccessful, especially in the more developed regions that are dominated by highly competent local governments. The lengthy negotiation process that preceded the construction of the Guangzhou-Zhuhai railway was such as case in point (Xu and Yeh, 2013). Yet,

\footnotetext{
7 "Promotion tournament model" is commonly used to delineate the mechanism of political promotion for Chinese government officials, which is based on sequential contests at each hierarchical point and only winners will have the opportunity to compete for higher posts. The assessment of officials is primarily based on their economic performance (Zhou, 2007).
} 
in a small inland city like Jiyuan, regional cooperation, especially with upper-level cities, remains as a key strategy for incorporation into the process of globalization. Jiyuan's efforts to secure FDI, in particular the Foxconn project, demand a complex process of power and capital rescaling. The new international division of labor enables Jiyuan to take up a position in the global production network of multinational corporations by connecting closely to Zhengzhou the capital of Henan Province - and taking advantage of its abundant and relatively low-cost land and labor resources. More importantly, competition from above, i.e. at a national and provincial level, grants Jiyuan with an indispensable role in the new round of capital accumulation, in which it can take advantage of the glocalization strategies of multinational corporations and the desires of local government for globalization.

It is notable that Jiyuan's disadvantaged position does not necessary make it a passive receiver of entrepreneurial policies. The local government has innovatively modified entrepreneurial policies learned from elsewhere to fit the local situation, and has diffused its successful experiences to other places. The politics of scale in the Jiyuan case have also involved unconventional institutional innovations, e.g. the upgrading of the city to a de facto prefecture city. Although entrepreneurial policies in Jiyuan are not as mature as those in developed coastal cities, the city, building on its successful economic performance, has taken a lead role in the circle of policy diffusion not only in close surroundings, but in Henan Province as a whole, and potentially even further afield. That said, policy diffusion in China is focused largely on economic competitiveness, and tends to overlook environmental sustainability and social equity, while being linked closely to the "promotion tournament model". Regardless of its size and position, the entrepreneurial city of Jiuyuan and its policies have been commodified, branded and extrospective.

Acknowledgement: We would like to thank Professor Fulong Wu and the three anonymous reviewers for their constructive comments. This research is supported by the National Natural Science Foundation of China (Project No.: 41671153) and the Research Grants Council of the Hong Kong SAR, China (Project No.: CRF/RGC C7028-16G). 


\section{References}

Biddulph, M. (2011). Urban design, regeneration and the entrepreneurial city. progress in planning, 76(2), 63-103.

Blunkett, D. and K. Jackson. (1987). Democracy in crisis: the town halls respond. London: Hogarth Press.

Brenner, N. (2000). "The urban question as a scale question: Reflection on Henri Lefebvre, urban theory and the politics of scale." International Journal of Urban and Regional Research 24(2): 361-378.

Brenner, N. (2013). Theses on urbanization. Public Culture, 25(1), 85-114.

Brenner, N., Peck, J. Theodore, N. (2010). "Variegated neoliberalization: geographies, modalities, pathways." Global networks 10(2): 182-222.

Caprotti, F. (2014). Critical research on eco-cities? A walk through the Sino-Singapore Tianjin Eco-City, China. Cities, 36, 10-17.

Cartier, C. (2015). "Territorial Urbanization and the Party-State in China." Territory, Politics, Governance 3(3): 294-320.

Chan, R. C. and Li, L. (2017). Entrepreneurial city and the restructuring of urban space in Shanghai Expo. Urban Geography, 38(5), 666-686.

Chapin, T. (2002). Beyond the entrepreneurial city: Municipal capitalism in San Diego. Journal of urban affairs, 24(5), 565-81.

Chen, Y., and H. Chen. (1996). "Jiyuan model" and economic development of Wuhan. Plan and market (1), 37-8 (in Chinese).

Chien, S.-S. (2013a). Chinese eco-cities: A perspective of land-speculation-oriented local entrepreneurialism. China Information, 27(2), 173-196.

Chien, S.-S. (2013b). New local state power through administrative restructuring-A case study of postMao China county-level urban entrepreneurialism in Kunshan. Geoforum, 46, 103-12.

Chien, S.-S., and Zhao, L. T. (2015). State-mediated knowledge transfer and resource mobility: a case study of china local government entrepreneurship. Issues and Studies, 51(2), 39-78.

Cox, K. R. (2013). "Territory, Scale, and Why Capitalism Matters." Territory, Politics, Governance 1(1): 46-61.

Doucet, B. (2013). "Variations of the Entrepreneurial City: Goals, roles and visions in Rotterdam's Kop van Zuid and the Glasgow Harbour Megaprojects." International Journal of Urban and Regional Research 37(6): 2035-2051.

Duckett, J. (2006). The entrepreneurial state in China: Real estate and commerce departments in reform era Tianjin, Routledge.

Harrison, J. (2008). "Stating the Production of Scales: Centrally Orchestrated Regionalism, Regionally Orchestrated Centralism." International Journal of Urban and Regional Research 32(4): 922-941. 
Harvey, D. (1989). "From managerialism to entrepreneurialism: the transformation in urban governance in late capitalism." Geografiska Annaler. Series B. Human Geography: 3-17.

Harvey, D. (2005). Neoliberalism 'with Chinese characteristics'. In A brief History of Neoliberalism, Harvey, D. Oxford University Press, pp:120-51.

He, S. and F. Wu (2009). "China's emerging neoliberal urbanism: perspectives from urban redevelopment." Antipode 41(2): 282-304.

He, S., \& Qian, J. (2017). From an emerging market to a multifaceted urban society: Urban China studies. Urban Studies 54(4): 827-846.

Hubbard, M. (1995). Bureaucrats and markets in China: the rise and fall of entrepreneurial local government. Governance, 8(3), 335-53.

Jessop, B., and N.-L. Sum. (2000). An entrepreneurial city in action: Hong Kong's emerging strategies in and for (inter) urban competition. Urban studies, 37(12), 2287-313.

Jia, J., Q. Guo, and J. Zhang. (2014). Fiscal decentralization and local expenditure policy in China. China Economic Review, 28, 107-22.

Landry, P. F. (2008). Decentralized authoritarianism in China: The Communist Party's Control of Local Elites in the Post-Mao Era (Vol. 6). New York: Cambridge University Press.

Li, L. (2015). State rescaling and national new area development in China: the case of Chongqing Liangjiang. Habitat International, 50, 80-89.

Li, Y. and F. Wu (2012). The transformation of regional governance in China: The rescaling of statehood. Progress in Planning 78(2): 55-99.

Liew, L. (2005). China's engagement with neo-liberalism: path dependency, geography and party selfreinvention. The Journal of Development Studies, 41(2), 331-52.

Luo, X., and J. Shen. (2007). Urban governance in cross-border coalitions: the case of the Jiangyin Economic Development Zone in Jingjiang, China. International Development Planning Review, 29(3), 353-77.

Ma, L. J. C. (2005). Urban administrative restructuring, changing scale relations and local economic development in China. Political Geography, 24(4), 477-497.

Ma, L. J. C. (2006). "The State of the Field of Urban China." China Information 20(3): 363-389.

MacKinnon, D. and J. Shaw (2010). "New State Spaces, Agency and Scale: Devolution and the Regionalisation of Transport Governance in Scotland." Antipode 42(5): 1226-1252.

McCann, E. (2011). Urban policy mobilities and global circuits of knowledge: toward a research agenda. Annals of the Association of American Geographers, 101(1), 107-30.

McCann, E. (2013). Policy boosterism, policy mobilities, and the extrospective city. Urban Geography, $34(1), 5-29$.

McCann, E., \& Ward, K. (2010). Relationality/territoriality: Toward a conceptualization of cities in the world. Geoforum, 41(2), 175-184. 
McCann, E., \& Ward, K. (2012). Policy assemblages, mobilities and mutations: toward a multidisciplinary conversation. Political studies review, 10(3), 325-332.

McMaster, R. and E. Sheppard (2004). Introduction: Scale and Geographic Inquiry. In Scale and Geographic Inquiry: Nature, Society, and Method. E. Sheppard and R. McMaster (Eds.) Oxford, Blackwell, 1-22.

Peck, J. (2011). Geographies of policy From transfer-diffusion to mobility-mutation. Progress in Human Geography, 35(6), 773-97.

Peck, J., and N. Theodore. (2010). Mobilizing policy: Models, methods, and mutations. Geoforum, 41(2), $169-74$.

Peck, J., \& Zhang, J. (2013). A variety of capitalism... with Chinese characteristics? Journal of Economic Geography, 13(3), 357-396.

Peterson, P. E. (1981). City limits: University of Chicago Press.

Qian, Z. (2011). Building Hangzhou's new city center: Mega project development and entrepreneurial urban governance in China. Asian Geographer, 28(1), 3-19.

Rees, G., and J. Lambert. (1985). Cities in crisis: The political economy of urban development in postwar London. London: Edward Arnold.

Robinson, J. (2002) Global and World Cities: A view from off the map. International Journal of Urban and Regional Research, 26(3), 531-554.

Shen, J., \& Wu, F. (2012). The development of master-planned communities in Chinese suburbs: a case study of Shanghai's Thames town. Urban Geography, 33(2), 183-203.

Smith, N. 1993: Homeless/global: scaling places. In Bird, J., editor, Mapping the Futures, Routledge, London, 87-119.

Stone, D. (1999). Learning lessons and transferring policy across time, space and disciplines. Politics, 19(1), 51-59.

$\mathrm{Su}, \mathrm{X}$. (2015). Urban entrepreneurialism and the commodification of heritage in China. Urban Studies, 52(15), 2874-2889.

Swyngedouw, E. and N. C. Heynen (2003). "Urban Political Ecology, Justice and the Politics of Scale." Antipode 35(5): 898-918.

Ward, K. (2011). Entrepreneurial urbanism, policy tourism, and the making mobile of policies. in The New Blackwell Companion to The City, Eds G Bridge and S Watson (Oxford: WileyBlackwell), 726-737.

$\mathrm{Wu}, \mathrm{F}$. (2003). The (post-) socialist entrepreneurial city as a state project: Shanghai's reglobalisation in question. Urban studies, 40(9), 1673-98.

Wu, F. (2012). China's eco-cities. Geoforum, 43(2), 169-171.

Wu, F. (2015) Planning for Growth: Urban and Regional Planning in China. Routledge, London.

Wu, F. (2016a) Emerging Chinese Cities: Implications for Global Urban Studies. The Professional Geographer 68, 338-48. 
Wu, F. (2016b). China's Emergent City - Region Governance: A New Form of State Spatial Selectivity through State - orchestrated Rescaling. International Journal of Urban and Regional Research, 40(6), 1134-1151.

Wu, F., \& Zhang, J. (2007). Planning the competitive city-region: The emergence of strategic development plan in China. Urban Affairs Review, 42(5), 714-740.

$\mathrm{Xu}$, J., and A. G. O. Yeh. (2005). City repositioning and competitiveness building in regional development: new development strategies in Guangzhou, China. International journal of urban and regional research, 29(2), 283-308.

$\mathrm{Xu}$, J., and A. G. O. Yeh. (2013). Interjurisdictional Cooperation through Bargaining: The Case of the Guangzhou-Zhuhai Railway in the Pearl River Delta, China. The China Quarterly, 213, 130-51.

Zhang, J. (2012). From Hong Kong's capitalist fundamentals to Singapore's authoritarian governance: the policy mobility of neo-liberalising Shenzhen, China. Urban Studies, 49(13), 2853-71.

Zheng, J. (2011). 'Creative industry clusters' and the 'entrepreneurial city'of Shanghai. Urban studies, 48(16), 3561-82.

Zhou, L. (2007). Governing China's Local Officials: An Analysis of Promotion Tournament Model. Economic Research Journal, 7, 36-50 (in Chinese). 